\title{
Liberal Çokkültürcülük: (Çok)Ulusalcı Liberalizm ve Azınlık-içindeki-Azınlıklar Sorunsalı
}

\section{Aret Karademir}

Özet: 20. yüzyılın son çeyreğinde, çıkış noktasını mensubu olduğu kültüre, ulusa veya devlete karşı korunması için bireysel haklarla donatılmış ve içerisinde yetiştiği kültürü rasyonel yetileri ile değerlendirip terk edebilme gücüne sahip "birey" anlayışında bulan "bireyci" liberalizmin içerisinden, bireylerin "kültürel" varlıklar olduklarını, bireysel özgürlüğün "kültürlerin korunması" olmaksızın icra edilemeyeceğini, bunun için de "kültürel azınlık hakları"nın liberalizmin olmazsa olmazı olduğunu savunan "liberal çokkültürcülük" doğmuştur. Bu yazıda, liberal çokkültürcülüğün en önemli versiyonlarından biri olan "(çok)ulusalcı liberalizm” incelenecek ve onun kadınlardan, LGBTİ bireylerinden ve dini veya mezhepsel muhaliflerden oluşan "azınlık-içindeki-azınlık" gruplarının ortaya çıkardığı çoğulculuğu kapsayacak teorik araçlar geliştiremediği; bu yüzden de yeterince çoğulcu olmadığı iddia edilecektir.

Anahtar sözcükler: Liberalizm, çokkültürcülük, ulusalcılık, azınlık hakları, azınlık-içindeki-azınlıklar.

\section{Liberal Multiculturalism: (Multi)Nationalism and the Problem of Minorities- within-Minorities}

\begin{abstract}
In the last quarter of the 20th century, liberal multiculturalism was born out of individualistic liberalism. Whereas the latter takes as its starting point the individual, who is supposed to be protected against the intrusions of his/her culture, nation, or state via individual rights, and who is capable of leaving the cultural heritage s/he was raised into; the former takes human beings as cultural entities, and defends that individual freedom cannot be performed without the protection of culture and that cultural minority rights are the sine qua non for liberalism. In this essay, I will examine one of the most important versions of liberal multiculturalism, namely (multi)national liberalism, and argue that it is not pluralistic enough due to the fact that it has not created the necessary tools to accommodate the sort of pluralism that is formed out of minorities-withinminorities.
\end{abstract}

Keywords: Liberalism, multiculturalism, nationalism, minority rights, minoritieswithin-minorities.

Karademir, Aret. (2017). Liberal Çokkültürcülük: (Çok)Ulusalcı Liberalizm ve Azınlık-içindekiAzınlıklar Sorunsalı. Kilikya Felsefe Dergisi (1). ss. 19-41 


\section{Giriş}

Günümüz dünyasında neredeyse hiçbir ulus-devlet tek-uluslu değildir. Aksine, modern ulus-devletlerin çoğu içlerinde farklı dilleri anadili kabul eden, farklı etnik ve ulusal kimlikleri ile kendi benliklerini tanımlayan, farklı tarihsel anlatıları kültürel mirası addeden ve farklı kültürel pratikleri etnik veya ulusal kimliklerinin ayırt edici öğeleri olarak algılayan insan topluluklarından oluşur (Gurr, 2000). Buna karşın liberal siyaset felsefesi, gerek modern gerekse çağdaş versiyonlarında, çokkültürlülük ve çokulusluluk temelli çoğulculuğu hesaba katacak teorileri, en azından genel olarak, çıkış noktasını kültüründen ve içerisine atıldığ kültürel anlam dünyasından bağımsız birey anlayışında bulduğundan geliştirmekte zorlanmıştır. Genel hatlarıyla söyleyecek olursak, tarihsel olarak liberal filozoflar, etnisite ve ulus temelli çoğulculuk karşısında iki temel stratejiden birini benimsemişlerdir. Birinci stratejiye göre, liberal normların toplumun her katmanına nüfuz etmesiyle birlikte insanlar etnik ve ulusal dar görüşlülük ile kültürel tikelliği geride bırakacak, zamanla evrensel liberal kültüre entegre olacaklardır. Bu bağlamda liberallerin yapması gereken, etnik ve ulusal azınlıkların kültürlerini korumalarını sağlayacak azınlık haklarını desteklemek ve çokulusluluk ile etnisite temelli çokkültürlülüğü koruma altına almak değil; azınlık kültürlerinin ilerleme, liberalleşme ve evrenselleşmenin tarihsel taşıyıcısı olan büyük ve gelişmiş uluslara asimile olmaları gerektiğini savunmaktır. Örneğin John Stuart Mill'e göre, bir İskoç'un Britanya'ya veya bir Bask'ın Fransa'ya bağlanması, "dünyanın genel devinimine katılmaksızın kendi kayalıklarına ve geçmiş zamanların yarı-ilkel kalıntılarına çekilmesinden" çok daha iyidir (Mill, 1972, ss. 363-364). ${ }^{1}$

İkinci stratejiye göre ise, etnik ve ulusal çoğulculuğun liberalizmin yaygınlaşmasıyla yok olacağını düşünmek için herhangi bir sebep yoktur. Ama bu, azınlıkların etnik ve ulusal kültürlerini korumayı amaçlayan kültürel hakları savunmayı gerektirmez. Vicdan ve düşünce özgürlüğü, siyasi özgürlük, ifade özgürlüğü veya seyahat özgürlüğü gibi bireysel/ liberal temel hak ve özgürlüklerin etnisite gözetmeksizin güvence altına alınması yeterlidir. Örneğin John Rawls'a göre, adaletin temel iki ilkesi-“diğerlerinin özgürlükleri ile uyumlu olmak koşulu ile her insanın mümkün olan en geniş kapsamlı temel özgürlüklere eşit hakkının olması" gerektiğini ve "sosyo-ekonomik eşitsizlikler"in ancak ve ancak

1 Bu yazıdaki tüm alıntılar İngilizce asıllarından Türkçeye yazar tarafından tercüme edilmiştir. 
"fırsat eşitliği koşullarında" herkese açık mevkilere bağlanıp, toplumun ekonomik anlamda "en talihsiz" kesiminin yararına olmaları koşuluyla kabul edilebileceğini söyleyen ilkeler-ile yönetilen toplumlar adil ve hakkaniyetli toplumlardır (Rawls, 1999, s. 266). Rawls için adaletin temel ilkelerini benimseyen bir toplum, herhangi bir kültürü veya kültürel iyi anlayışını "doğrudan" desteklemiyorsa, toplumun genel/çoğunluğa ait kültürel altyapısının ulusal, etnik veya dini alt-kültürlerin yaşama şansını orantısızca etkiliyor oluşu herhangi bir hakkaniyetsizlik veya adaletsizlik durumu oluşturmaz (Rawls, 1999, ss. 192-197). Dahası, azınlık kültürü mensuplarına "orantılı doyum" yaşatabilmek adına kaynak ayırmak "bölücü" bir faaliyettir ve liberaller tarafından kesinlikle reddedilmelidir (Rawls, 2005, ss. 329-330).

Sonuç olarak bireyci liberal felsefe, tarihsel olarak ve genellikle, etnisite ve ulus kökenli çoğulculuğu kapsayan teoriler üretmek yerine, azınlık kültürlerine ya "iyi niyetli ihmal" ve "kültürel tarafsızlık" kavramlarıyla yaklaşmış, ya da etnik ve ulus kültürleri ile bu kültürlere bağlılıkların zamanla yok olmasını umut etmiştir. Ne var ki 20. yüzyılın son çeyreği, bu iki stratejinin de yetersiz olduğunu gözler önüne sermiştir. Bir taraftan Bask, Quebec, Katalan milliyetçiliği; diğer taraftan "Yeni Dünya" yerlilerinin her türlü katliam ve asimilasyon politikası karşısında kültürel farklılıklarını koruma çabası; öte yandan Sovyet Sosyalist Cumhuriyetler Birliği ile Yugoslavya Sosyalist Federal Cumhuriyeti'nin dağılması sonucu ortaya çıkan ulus ve etnisite temelli çatışmalar, ulusal ve etnik bağlılıkların zamanla yok olması umudunu boşa çıkarmış, iyi niyetli ihmal ile kültürel tarafsızlığın birer mitten ibaret olduklarını göstermiştir. İyi niyetli ihmal ve kültürel tarafsızlık birer mittir; çünkü bireysel hak ve özgürlüklerin korunması, çokulusluluk ve çokkültürlülük temelli sorunlara çözüm olmadığı gibi, iyi niyetlilik ve kültürel tarafsızlık kisveleri altında çoğunluk kültürünü koruyup azınlık kültürlerinin yok olması için kullanılabilir - ve kullanılmıştır. Örneğin ifade özgürlüğü ve eğitim hakkı, bireylerin hangi dilde düşüncelerini ifade edip hangi dilde eğitim almaya haklarının olduğu hakkında herhangi bir şey söylemez. Seyahat özgürlüğü, etnik çoğunluk mensupları ile göçmenlerin, ulusal azınlığın çoğunluk kültürü oluşturduğu bölgelere yerleşmelerini teşvik edici politikalarla birleştiğinde, azınlık kültürünün kendi yurdunda da azınlıklaşması ve gücü ile çekiciliğini yitirmesi için kullanılabilir-ve kullanılmıştır. Benzer bir şekilde, oy verme özgürlüğü gibi siyasi bir özgürlük, seçim bölgelerinin veya federasyon, valilik, muhtarlık gibi birimlerin sınırlarının özenle çizilmesi sonucu, etnik azınlığın kendi 
bölgesinde de azınlıklaşmasına veya siyasi bir birim oluşturacak bütünlüğe ulaşamamasına; dolayısıyla kendi bölgesinin toplumsal ve kurumsal kültürünü belirleyip ayakta tutacak güçten yoksunlaşmasına yol açmak için kullanılabilir-ve kullanılmıştır (Kymlicka, 1995; Kymlicka, 2007; McGarry, 1998; Penz, 1992).

Tüm bu gelişmeler ışığında, azınlık hakları ile çokkültürlülük ve çokulusluluk tartışmalarının 20. yüzyılın sonlarına doğru uluslararası siyasi arenada kendilerine yer bulmaya başlamaları şaşırtıcı değildir. Örneğin Avrupa Güvenlik ve İşbirliği Konferansı, 1991 yılında Ulusal Azınlıkların Hakları üzerine bir bildirgeyi benimsemiştir. Birleşmiş Milletler, Ulusal ya da Etnik, Dinsel ve Dilsel Azınlıklara Ait İnsanların Hakları Bildirgesi (1993) ile Yerli Halkları Evrensel Bildirgesi Taslağı (1988) üzerinde tartışmaya başlamıştır. Bölgesel ya da Azınlık Dilleri için Avrupa Şartı ise 1992 yılında Avrupa Konseyi tarafından benimsenmiştir. Bu bildirgelerin hepsi liberal çerçeve içerisinde yazılmış; kültürel hakların temel insan haklarını askıya alacak şekilde yorumlanmaması gerektiği vurgulanmıştır (Kymlicka, 1995, s. 5). Aynı yıllarda liberal siyaset felsefesi içerisinden de liberal çokkültürcülük teorileri doğmaya başlamıştır. Genel olarak, liberal çokkültürcülük teorileri, kültürel çoğulculuk karşısında yapılması gerekenin azınlıklara kültürel haklar tanımak olduğunu, bu hakların kültürlerin korunmasından çok bireylerin refahı için elzem olduğunu; dolayısıyla kültürel hakların bireyci liberalizmin benimsediği temel insan hakları ile çelişmek bir yana, liberal teori tarafından zorunlu kılındığını iddia eder.

$\mathrm{Bu}$ yazıda, liberal çokkültürcülüğün en önemli versiyonlarından biri olan ve (çok)ulusalcı liberalizm olarak adlandırabileceğimiz teoriler incelenecek ve bahsi geçen teorilerin yeterince çoğulcu olmadıkları iddia edilecektir. Genel olarak, (çok)ulusalcı liberalizme göre, bireyler etnik ve ulusal kültürlerinden bağımsız düşünülemez; çünkü etnik ve ulusal kültür, o kültüre mensup bireylerin anlamlı seçimler yapmalarını, anlamlı bir hayat yaşamalarını ve dolayısıyla liberalizmin benimsediği temel hak ve özgürlüklerden özgürce yararlanmalarını mümkün kılan anlam bağlamıdır. Ancak çokuluslu ulus-devletler, etnik ve ulusal azınlıklar için kültürel hakları benimsemedikleri müddetçe, azınlık ulusuna mensup bireylerin kültürlerini çoğunluk kültürü karşısında ölüme terk etmiş olacaklardır; dolayısıyla toplumun bir kesiminin temel hak ve özgürlüklerden özgürce yararlanmasını mümkün kılarken, diğer kesimleri anlamsız bir hayata mahkûm edeceklerdir. Bu yüzden etnik ve 
ulusal azınlıklar için kültürel haklar elzemdir. Yalnız bu hakların amacı, bireylerin temel hak ve özgürlüklerden özgürce yararlanabilmeleri olduğundan, azınlık hakları bireyleri baskı altına almak ve onları kültürleri ile uyum içerisinde yaşamaya zorlamak için kullanılamaz. $\mathrm{Ne}$ var ki, aşağıda gösterileceği üzere, (çok)ulusalcı liberalizm - özellikle söz konusu azınlık kadınları, LGBTİ bireyleri ve azınlık kültürü içerisindeki dinsel veya mezhepsel azınlık-içindeki-azınlıklar olduğunda-bu tür baskıları engelleyecek teorik araçlardan yoksundur.

Yazının ikinci bölümünde, sadece (çok)ulusalcı liberalizmin değil aynı zamanda da liberal çokkültürcülügüun akademideki en ünlü ve en güçlü savunucularından olan Will Kymlicka felsefesi incelenecektir. Üçüncü ve dördüncü bölümler liberal siyaset felsefesi sınırları içerisinde milliyetçiliği yeniden canlandırmaya çalışan Yael Tamir ve David Miller'a ayrılacaktır. Beşinci bölümde (çok)ulusalcı liberalizmin, içerisinde nasıl bir anti-liberalizme kayma tehlikesi barındırdığı Joseph Raz, Avishai Margalit ve Moshe Halbertal üzerinden gösterilecektir. Yazının son bölümünde, genelde liberal siyaset felsefesinin, özelde ise (çok)ulusalcı liberalizmin kültürel çoğulculuk ile başa çıabilmek için nelere ihtiyaç duyduğu tartışmaya açılacaktır.

\section{Kymlicka ve Toplumsal Kültür}

Kymlicka, etno-kültürel azınlık haklarının liberalizmin "temel prensipleri" ile uyuşmak bir yana, bu prensipler tarafından zorunlu kılındığını iddia eder. Bahsi geçen prensipler, bir yaşam tarzı "seçme" ve seçilen tarzı gözden geçirip "değiştirme" özgürlüklerini kapsayan "bireysel özgürlük prensipleri" ne tekabül eder (Kymlicka, 1995, ss. 75, 80). Yalnız Kymlicka için insanlar, içerisinde yetiştikleri toplumdan ve o toplumun kültüründen bağımsız seçimler yapabilen, atomik ve izole varlıklar değillerdir. Aksine, insanlar kültürel varlıklardır ve dolayısıyla anlamlı seçimler yapmalarını mümkün kılan toplumsal ve kültürel anlam bağlamı sayesinde bireysel özgürlüklerini icra edebilirler. Kymlicka neyin anlamlı/neyin anlamsız ve neyin seçilmeye değer/neyin seçilmeye değmez olduğunu belirleyen anlam bağlamına "toplumsal kültür" adını verir. Toplumsal kültürle de "nevi şahsına münhasır bir dili ve kültürü paylaşan, belirli bir toprak parçası ya da yurtta yoğunlaşmış, kurumsal bütünlüğe sahip tarihsel cemaat" kültürünü anlar (Kymlicka, 1995, s. 11). Toplumsal kültürün "pratikleri ve kurumları hem özel hem de kamusal alandakiler dâhil olmak üzere insani etkinliklerin tümünü kapsar" ve o kültürün mensuplarına 
"sosyal, eğitimsel, dini, eğlence ve ekonomik hayatı kapsayan" her alanda "anlamlı yaşam tarzı" seçenekleri sunar (Kymlicka, 1995, ss. 75-76).

Toplumsal kültürü “bir toprak parçası üzerinde yoğunlaşmış olmak" ve "kurumsal bütünlük" kavramları üzerinden tanımladığı için, Kymlicka toplumsal kültür ile ulus kültürünü eş anlamlı kullanır ve "aynı toplumsal kültürlerin neredeyse her zaman ulusal kültürler oldukları gibi, ulusların da neredeyse her zaman toplumsal kültürler oldukları"nı iddia eder (Kymlicka, 1995, s. 80). Kymlicka'ya göre toplumsal kültür, modern ulus-devletlerin toplumun her katmanina "ekonomik, siyasi ve eğitim kurumlarında vücut bulacak olan" ortak bir kültürü ulusal medya, standart eğitim, askerlik hizmeti ve dil ile vatandaşlık yasaları aracılığıyla nüfuz ettirme politikasının bir ürünüdür (Kymlicka, 1995, s. 76). Bahsi geçen ortak kültür, büyük oranda, toplumsal çoğunluğun etnik ve ulusal bilincini yansıtır ve dolayısıyla etnik ve ulusal azınlık kültürlerini "toplumsal çoğunluğun [kültürel,] ekonomik ve politik kararları" karşısında yok olmaya mahkûm eder (Kymlicka, 2001, s. 146). Dahası, ulus-devletler isteseler dahi çoğunluk kültürünü kayırmaktan ve azınlık kültürlerini ölüme terk etmekten vazgeçemezler; çünkü ulus-devletler hangi dilin resmi dil olacağını, seçim bölgelerinin sınırlarının nasıl çizileceğini, hangi günlerin ulusal veya dini bayram/tatil addedileceğini ve hangi sembollerin ulusal semboller olarak algılanacağın belirlemek zorundadır. Bu da toplum içerisindeki bazı kültürlerin desteklenmesine, diğerlerinin ise marjinalleştirilmesine yol açacaktır. Dolayısıyla Kymlicka için etno-kültürel azınlık hakları, "devletin ulus inşası politikalarına karşı [azınlık kültürlerini] koruyacak bir cevap" olarak algılanmalı ve "bireysel özgürlüğün kültüre bağlı ve bağımlı olduğu" ile ulus-devletlerin çoğunluk kültürünü yaşatıp azınlık kültürlerini ölüme terk ettikleri göz önünde bulundurulduğunda, bu tür hakların insanların bireysel özgürlüklerden eşit oranda yararlanmalarını mümkün kılmak için elzem oldukları sonucuna varılmalıdır (Kymlicka, 1995, s. 75; Kymlicka, 2001, s. 2).

Kymlicka'ya göre, azınlık haklarının amacı insanların bireysel özgürlüklerden eşit oranda yararlanmalarını mümkün kılmak olduğu için, buhaklarazınlıkkültürümensuplarınıkendikültürleriningelenekselyaşam tarzını benimsemeye zorlayan "iç kısıtlamalar" formunda değil; azınlıklar için anlam bağlamı olma işlevi gören kültürleri toplumsal çoğunluğa, ulusdevlet politikalarına ve zorunlu veya dolaylı asimilasyon olgularına karşı korumayı amaçlayan "dış korumalar" formatında olmalıdır (Kymlicka, 1995, s. 8). Ayrıca bahsi geçen hakların içeriği de azınlık gruplarının 
doğasına uygun olarak belirlenmelidir. Etno-kültürel azınlıkları iki gruba ayırmak mümkündür. Birinci grup, "öncesinde öz-yönetime sahip ve bir toprak parçası üzerinde yoğunlaşmış kültürlerin [ulus-]devlet çatısı altına sokulmaları" yla ortaya çıkan "ulusal azınlıklar"dan oluşur; bu azınlıklar "çoğunluk kültürü ile yan yana yaşayan ayrı bir toplum olarak kültürel hayatlarını sürdürmek isterler" (Kymlicka, 1995, s. 10). İkinci grup ise "bireysel veya aile olarak göç" olgusundan doğar ve bu grubu oluşturan bireyler "etnik kimliklerinin hali hazırdakinden daha fazla tanınmasını" arzu ediyor olsalar dahi, "genellikle toplumun geri kalanı ile bütünleşmeyi isterler" (Kymlicka, 1995, ss. 10-11). Kymlicka birinci gruba dâhil azınlıklar için federasyon veya rezervasyon sistemi gibi uygulamalarla desteklenen "öz-yönetim hakları," parlamento gibi kurumlarda "özel temsil hakları," kültürü etkileyen konularda "veto hakları," azınlık dilleri için "resmi dil statüsü" veya "azınlık dilinde üniversiteler, okullar ve medya için kamu fonu ayrılması"nın uygun olacağını düşünür (Kymlicka, 1995, ss. 27-33; Kymlicka, 2007, s. 71). Göçmenler için ise, onları etno-kültürel farklılıkları sebebiyle hayatın birçok alanında "dezavantajlı duruma düşüren yasa ve uygulamalardan muafiyet," "kültürel pratikleri için farklı kamusal fonlar," "pozitif ayrımcılık," "eğitim müfredatında değişiklikler" ve "iki dilde eğitim" uygundur (Kymlicka, 1995, ss. 27-32; Kymlicka, 2001, s. 163).

Ne var ki her ne kadar Kymlicka, liberal felsefesi içerisine, insanların kültürel varlıklar oldukları gerçeğini sokmuş ve etnisite veya ulus kökenli çoğulculuğa iyi niyetli ihmal ve kültürel tarafsızlık kavramlarıyla yaklaşmamış olsa da; Kymlickacı (çok)ulusalcılık, ilk bakışta fark edilenin aksine, yeterince çoğulcu değildir. İlk olarak, Kymlicka aksini iddia etse de, Kymlickacı liberalizmin göçmenler hakkında söyleyecek çok fazla sözü yoktur. Bunun sebebi, Kymlicka'nın toplumsal kültürü bireysel özgürlüklerin icra edilebilmeleri için bir ve tek önkoşul addetmesi ve bahsi geçen toplumsal kültürü "bir toprak parçası üzerinde yoğunlaşmış olmak" ve "kurumsal bütünlük" kavramları üzerinden tanımlamasıdır. Oysa göçmen toplulukları genel olarak kurumsal bütünlükten uzaktır: Okulları, parlamentoları, hastaneleri veya medya kuruluşları yoktur (Carens, 2010, ss. 56-59; Modood, 2013, ss. 29-33). Ayrıca birçok "Yeni Dünya" yerli kabilesi ile Avrupa ve Orta Doğu'daki birçok ulusal azınlık grubu da kurumsal bütünlükten uzaktır; hatta birçok örnekte olduğu gibi, bir toprak parçası üzerinde yoğunlaşmamış, vatandaşı oldukları ülke içerisine gelişigüzel dağılmış veya o ülkenin genel kültürüne değişen oranlarda entegre olmuşlardır (Levy, 2003, ss. 119-135). Bu durumda göçmenler ve bir bölgede yoğunlaşmamış ulusal azınlık grupları niye 
kültürel haklara sahip olmalılar da, kurumsal bütünlüğe sahip çoğunluk kültürüne asimile olmamalılar sorusuna Kymlicka'nın verebileceği bir cevap yoktur.

İkinci olarak, Kymlicka'nın iddia ettiğinin aksine, insanlar bireysel seçimlerini anlamlı kılacak anlam bağlamını sadece ulus kültüründe bulmazlar; bazen din veya mezheplerinde, bazen de toplumsal cinsiyet veya ırklarında bu bağlama sahip olurlar. Bazı durumlarda ise birçokları için anlam bağlamı olan ulus kültürü, diğerleri için-özellikle mezhepleri veya toplumsal cinsiyetleri dolayısıyla - anlamsızlık bağlamı işlevi görür. Örneğin heteroseksist bir ulus kültür; gey, lezbiyen ve transseksüellerin birçok seçimini anlamsız kılar, bireysel özgürlüklerini icra etme kapasitelerini sınırlandırır. Heteroseksist bir kültürün LGBTİ bireylerinin bireysel özgürlüklerini icra etme kapasitelerini sınırlandırması, illa Kymlicka'nın iç kısıtlamalar olarak adlandırıp reddettiği anti-liberal uygulamalarla olmak zorunda da değildir. Aynı ulus-devletlerin toplum içerisindeki bazı kültürleri destekleyip diğerlerini marjinalleştirmeleri gibi, hegemonik toplumsal cinsiyet kültürü de neyin anlamlı/neyin anlamsız olduğunu heteroseksüel bir perspektiften belirleyecek; bu perspektifin gözünde "yeterince" erkeksi veya kadınsı görünmeyen, giyinmeyen, konuşmayan veya davranmayanları herhangi bir anti-liberal hak kısıtlamasına gitme ihtiyacı duymadan marjinalleştirecektir. Kymlicka'nın kelimeleri ile söyleyecek olursak; böyle bir kültür, cinsel azınlıkların erkeklik veya kadınlık normu yorumlarını, "toplumsal çoğunluğun [kültürel,] ekonomik ve politik kararları" karşısında yok olmaya mahkûm edecektir. Sonuç olarak, Kymlicka'nın etnik ve ulusal azınlıklar için öngördüğü kültürel hakları cinsel azınlıklar için genişletmemesinin sebebini anlamak güçtür-özellikle de, Daniel Weinstock'ın (2002) da işaret ettiği gibi, azınlık hakları aracılığıyla oluşturulan, korunan veya güçlendirilen "farklı eşcinsel organizasyonların eşcinsel hayat tarzını daha 'seçilebilir' kılıp; eşcinselleri, [bu tür organizasyonların yokluğunda,] toplumsal çoğunluğun değer yargılarını benimsemeleri sonucu ortaya çıkan kendinden iğrenme ve kendinden şüphe etme olgularına karşı koruma" ihtimali olduğu düşünüldüğünde (s. 247).

Son olarak, Kymlicka tek anlam bağlamı olarak kavramsallaştırdığı ulus kültürünü homojen, monolitik ve statik bir varlık olarak kurgular. Başka bir deyişle, Kymlicka kültürün-daha doğrusu o kültürün hegemonik yorumunun-ortodoks olmayan din, mezhep veya toplumsal cinsiyet yorumlarının eleştirilerine, meydan okumalarına, revizyon 
taleplerine veya sessiz protestolarına maruz kalmadan toplumun her kurum ve pratiğine nüfuz edeceğini ve hayatın her alanında "anlamlı yaşam tarzı" seçenekleri sunacağını düşünür. Oysa bu düşünce yanlış bir düşüncedir; çünkü özellikle muhafazakâr toplumlardaki hegemonik toplumsal cinsiyet normları yorumuna savaş açan kadınlardan, LGBTI bireylerinden ve dinsel veya mezhepsel nedenlerle ulus kültürünü hegemonik anlayıştan farklı yorumlamak isteyenlerden oluşan azınlıkiçindeki-azınlık gruplarını göz ardı eder (Benhabib, 2002, ss. 59-67; Carens, 2010, ss. 64-73). Bu tür bir göz ardı etmenin, Kymlicka felsefesi için ilk bakışta fark edilenden çok daha yıkıcı sonuçları olacaktır. Örneğin, eğer, Kymlicka'nın iddia ettiği gibi her toplumsal kültür bir ulus kültürü ise; dahası, bahsi geçen ulus kültürü insanların bireysel özgürlüklerini icra etmelerini mümkün kılan tek anlam bağlamı ise ve bu anlam bağlamı, azınlık-içindeki-azınlıkları göz ardı etmek pahasına homojen bir varlık olarak kurgulanmışsa; Kymlicka'nın, mensuplarını toplumsal kültüre uygun davranmaya zorlayan iç kısıtlamalara niye karşı çıktığı kendi felsefesinin perspektifinden anlaşılır değildir-özellikle de yerel çoğunluk dinsel, mezhepsel veya toplumsal cinsiyete dair "anormallikleri" ve "sapkınlıkları" kendi toplumsal kültürlerini, yani tek anlam bağlamlarını ve dolayısıyla bireysel özgürlüklerini tehdit edici unsurlar olarak görüyorsa. Ayrıca Kymlicka'nın iç kısıtlamalar ve diş korumalar arasında yaptığı ayrım da çoğu zaman geçerli bir ayrım değildir. Örneğin yerli halkların kültürlerini korumak adına, yerli olmayanların yerli rezervasyonlarından mülk satın almalarını yasaklamak (dış koruma), herhangi bir yerlinin, rezervasyondaki mülkünü satıp elde ettiği gelirle yeni bir yaşam tarzı benimseme seçeneğini elinden almak, onu geleneksel yaşam tarzına mahkûm etmek anlamına gelebilir (iç kısıtlama) (Levy, 2000, ss. 117-118). Dış koruma ile iç kısıtlamanın bu denli iç içe geçtiği durumlarda da azınlık-içindeki-azınlıkları göz ardı ederek etno-kültürel hak formüle etmek, dini, mezhepsel veya cinsel azınlıkları etnik ve ulusal azınlıklara yem etmek anlamına gelir.

Sonuç olarak Kymlicka felsefesi, insanların bireysel özgürlüklerini yaşayabilmeleri için korunması gereken anlam bağlamını tek-yönlü, monolitik, statik ve homojen bir varlık olarak kurgulamış; bu yüzden de (çok)ulusalcı liberalizmini yeterince çoğulcu kılamamıştır. Bir sonraki bölümde, ulusal anlam bağlamını Kymlicka'nınkinden daha çok-yönlü, devinimsel ve heterojen bir varlık olarak kurgulayan Tamirci liberal çokkültürcülük incelenecek ve Tamir'in azınlık-içindeki-azınlıkların oluşturduğu çoğulculuk karşısında kapsayıcı bir teori geliştirip 
geliştiremediği tartışmaya açılacaktır.

\section{Tamir ve Liberal Milliyetçilik}

Tamir liberalizm ile milliyetçiliğin birbirine zıt iki ideoloji olarak algılanmak zorunda olmadıklarını iddia eder. Aksine, liberalizm ve milliyetçilik insan doğasının iki farklı yönüne işaret eden ideolojilerdir. Bir yandan, insanlar seçim yapabilen ve seçimleri üzerine düşünebilen özgür varlıklardır. Bu anlamda bireye ve bireysel özgürlüğe vurgu yapan liberalizm insanı anlamada doğru bir yoldadır. Öte yandan, insanlar toplumsal varlıklardır ve seçimleri ile hayat tarzlarını anlamlı kılan kültürel anlam bağlamı içerisinde bireysel özgürlüklerini icra ederler. Başka bir deyişle, insanlar ne kendilerini yoktan var eden atomik ve izole öznelerdir; ne de içerisine doğdukları kültürü sorgulama yetisinden yoksun sosyal otomatlardır. Yalnız Kymlicka'nın aksine, Tamir bahsi geçen anlam bağlamını ulus kültürü ile özdeşleştirmez; "toplumsal cinsiyet" in veya "dini mensubiyet"in bazı yaşamlar için ulus kültürünün sunacağından daha güçlü bir anlam bağlamı olma işlevi görebileceğinin farkındadır (Tamir, 1993, s. 155; Tamir, 1995, s. 431). Yine de ulus kültürü anlamlı seçimler yapabilmemizi mümkün kılan "bir"-tek değilönkoşuldur ve dolayısıyla liberalizm kadar milliyetçilik de insan doğasını anlamada doğru bir yoldadır (Tamir, 1993, s. 7).

Tamir'e göre bir insan topluluğunu ulus yapan, dil, tarih, din, irk ve etnisite gibi "ortak, objektif özelliklerden yeteri kadar"1na ve "ulus bilinci"ne sahip olmaktır (Tamir, 1993, ss. 65-66). Yalnız bahsi geçen objektif özellikler doğal nesneler değil, tarihsel kurgulardır. Başka bir deyişle, uluslar ortak ve çok geçmiş zamanlardan günümüze değişmeden süregeldiğine inanılan dil, ırk veya etnisite gibi özelliklerini farklılıkların "bilinçli unutuluşu ve tarihsel gerçekliğin yanlış betimlenmesi" sonucu elde ederler (Tamir, 1995, s. 439). Dolayısıyla, ulus olmanın "tek zorunlu koşulu sübjektiftir: ulus bilincine sahip olmak" (Tamir, 1991, s. 574). Bir ulusun kendini diğer uluslardan ayırmasına ve böylece ulus bilincini güçlendirmesine olanak sağlayan ise o ulusun kültürüdür. Tamir kültürle bireylerin birbirlerini aynı ulusun mensubu olarak algılamalarını mümkün kılan "davranış biçimleri, dil, toplumsal normlar, mitler ve semboller" bütününü anlar (Tamir, 1993, s. 68).

Her ne kadar ulusları ulus yapan "objektif” özellikler birer kurgudan ibaret olsalar da, Tamir için ulusların öz-yönetim hakkına sahip olmaları 
gerekmektedir; çünkü ulus kültürü, yukarıda gördüğümüz gibi, mensupları için anlam bağlamı olma özelliğine sahiptir ve "bir ulusun üyesi olmak bireylerin kimliklerini oluşturan en temel etkenlerden biridir" (Tamir, 1993, s. 74). Dolayısıyla, insanların "tatmin edici" ve "saygın" bir hayat sürdürmeleri, "kendilerini değerli bir cemaatin üyesi olarak algılayabilmelerine bağlıdır" (Tamir, 1993, s. 73). Yalnız bir bireyin ulusal kimliğini koruyabilmesi ve hakkıyla yaşayabilmesi, o kimliği "özel ve kamusal alanda ifade edebilmesine" ve kendisiyle aynı kimliği kamusal alanda ifade eden insanların varlığına bağlıdır (Tamir, 1993, s. 73). Bunun için de ulus kültürünü, o kültürün dilini, tarihini ve "hatta dinini" yansitan kurumlarla donatılmış "ortak kamusal alan"a ihtiyaç vardır (Tamir, 1993, s. 73). Tüm bunların olabilmesi için, ulusun, hem mensupları hem de mensubu olmayanlar tarafından kendi kamusal alanını, kültürünü ve kaderini belirleme yetisine sahip bir varlık olarak algılanması; yani özyönetim hakkına sahip olması gerekmektedir (Tamir, 1993, s. 74).

Tamir'e göre modern ulus-devletler, iyi niyetli ihmal ve kültürel tarafsızlık kisveleri altında, etnik ve ulusal çoğunluğun ulus kültürünü yaşamasını kolaylaştırırken, azınlıkların kültürlerini yaşamada dezavantajlı duruma düşmelerine sebep olur. Bunun nedeni, kültürel tarafsızlığın bir mitten ibaret olduğu gerçeğidir; çünkü modern refahdevletlerin dil, eğitim ve kültür alanındaki harcamaları "belirli bir [kültürel] değerler seti"ni yansitmaktadır (Tamir, 1993, s. 147). Dahas1, ulus-devletler çoğunluk kültürünü "siyasi kurumlarda," "resmi dilde," "kutlamaların/ayinlerin ve ulusal kahramanların seçiminde," "toplumsal objelere karşı takınılan psikolojik tavırda" ve "tarihin yorumlanmasında" yansitırlar (Tamir, 1993, s. 148). Ayrıca "politik sistemi kuranların, yasalar1 çıkartanların, kilit siyasi mevkileri işgal edenlerin ve devlet bürokrasisini yönetenlerin bir kültürü vardır ve bu kültürü siyasi arenaya taşımaktan geri durmaları imkânsızdır" (Tamir, 1993, s. 149). Sonuç olarak, azınlık ulus kültürüne iyi niyetli ihmal ve kültürel tarafsızlık kavramlarıyla yaklaşılmamalı; ulusal azınlıklar öz-yönetim hakkı ile donatılmalıdır. Yalnız öz-yönetim hakkı, illa azınlıkların kendi devletlerine sahip olmaları ile hayata geçmek zorunda değildir; çünkü "federatif veya konfederatif düzenlemeler, yerel özerklikler, [azınlık] ulusal kurumlarının tesisi" gibi uygulamalarla da öz-yönetim hakkı icra edilebilir (Tamir, 1993, s. 9). Bu uygulamalar ulus-devlete sahip olmakla aynı şeye, yani ulusların "emsalsiz kültürel özlerini" ve "ulusal ferdiyetlerini" korumalarına farklı oranlarda da olsa hizmet ederler (Tamir, 1991, s. 580; Tamir, 1993, s. 76). 
Ne var ki Tamirci (çok)ulusalcı liberalizm, aynı Kymlicka'nınkinde olduğu gibi, yeterince çoğulcu değildir. Yukarıda gördüğümüz üzere, Tamir felsefesinde ulus kültürü, mensupları için bir ve tek anlam bağlamı olma işlevi görmez; çünkü Tamir'e göre insanlar, ulusal mensubiyetleriyle kendi kimliklerini özdeşleştirebildikleri gibi, dinsel veya toplumsal cinsiyete dair kimliklerini de yaşamlarının merkezine koyabilirler. Bu noktada sorulması gereken soru, kişinin ulus kültürü dinsel, mezhepsel veya cinsel kimliğinin çatışması durumunda ne yapılması gerektiğidir. Tamir din, mezhep veya toplumsal cinsiyeti dolayısıla, heteroseksist veya dinin spesifik bir yorumu üzerinden tanımlanan ulus kültürünce anlamsızlığa itilen azınlık-içindeki-azınlık hayatları için ne söyleyebilir? Öncelikle, Kymlicka'nın aksine, Tamir ulus kültürünün, "içerisinde farklılıkları barındırmayan bir bütün" olmadığını ve aynı kültüre mensup olanların "tamamen farklı ve hatta çelişen yorumlar" ile kendi kültürlerini yorumluyor olabileceklerini vurgular (Tamir, 1999, s. 174). Bu yüzden de kültürel hakların, sadece hâlihazırdaki kültür yorumunu koruma özgürlügüne değil, aynı zamanda da kültürü "yeniden yaratma" özgürlüğüne gönderme yapan haklar olarak algılanmaları gerektiğini savunur (Tamir, 1993, s. 49). Dolayısıyla, Tamir'e göre kültürel haklar, ulus kültürü mensuplarının, geleneksel yaşam tarzını reddetme, ona alternatif kültür yorumları getirme, hatta başka bir kültüre "asimile olma" özgürlüklerini icra etmekten alıkonmaları için kullanılamazlar (Tamir, 1999, s. 164). Yalnız bahsi geçen özgürlüklerin hepsi negatif özgürlüklerdir: geleneksel yaşam tarzını reddetmekten, kültürü farklı yorumlamaktan ve asimile olmaktan alıkonmama özgürlüğü. Tamir cinsel, dini ve mezhepsel azınlıklar için negatif hakları uygun görürken, etnik ve ulusal azınlıklar için pozitif hakları savunur: öz-yönetim hakkı veya azınlık ulusal kurumlarının tesisi için kamusal fon hakkı.

Yukarıda gördüğümüz gibi, Tamir için pozitif hakların amacı, azınlık gruplarınıulusalçoğunluğun kendi kültürünü "siyasi kurumlarda," "resmi dilde," "kutlamaların/ayinlerin ve ulusal kahramanların seçiminde," "toplumsal objelere karşı takınılan psikolojik tavırda" ve "tarihin yorumlanmasında" yansıtıyor olduğu gerçeğine karşı korumaktır. Ne var ki aynı argüman din ve toplumsal cinsiyet bağlamında da kullanılabilir; çünkü neredeyse her modern ulus-devlet, heteroseksüel kültürünü ve kadınlıkveyaerkekliknormlarınınheteroseksüelyorumunu“"kutlamaların/ ayinlerin ve ulusal kahramanların seçiminde," "toplumsal objelere karşı takınılan psikolojik tavirda" ve "tarihin yorumlanmasında" yansitır. $\mathrm{Bu}$, özellikle ulusal kahramanların neredeyse hepsinin heteroseksüel 
kadın veya erkek rolüne uygun giyinen, davranan, konuşan rol modeller oldukları; heteroseksüel çekirdek ailenin romantik komedilerden sosyal devletin aile politikalarına kadar hayatın birçok alanında rakip tanımadan kutlanıp kutsanıyor olduğu ve dominant kültürün moda endüstrisine veya profesyonel giyim objelerine heteroseksüel psikoloji ile yaklaştığ1 düşünüldügünde doğrudur.

Etnik ve ulusal anlam bağlaminın dinsel, mezhepsel veya cinsel bağlamlar karşısında ayrıcalıklı bir konuma yerleştirilmesi-yani etnik ve ulusal azınlığın kültürünü anlamlı ve tatmin edici bir şekilde yaşamasını mümkün kılmak için pozitif haklarla donatıliyorken; dinsel, mezhepsel veya cinsel azınlıkların kendi kimliklerini etkileyen konularda veto hakkı benzeri pozitif haklardan mahrum bırakılmaları-Tamir felsefesi için ilk bakışta fark edilenden çok daha büyük bir soruna yol açar. Azınlıkiçindeki-azınlıkların ulus kültürüne alternatif yorumlar getirmeleri ile ulusların "emsalsiz kültürel özlerini" ve "ulusal ferdiyetlerini" koruma istekleri çoğu zaman birbiriyle çatışan olgulardır. Örneğin ulusal, etnik ve dini azınlıkların, kültürlerinin "emsalsiz özlerini" ve "ulusal ferdiyetlerini" korumak adına endişe ettikleri en temel konulardan biri, "evlilik, boşanma, çocuk velayeti, aile mülkünün bölüştürülmesi ve kontrolü ile miras"1 düzenleyen yasaları kendi iradeleriyle şekillendirme hakkına sahip olmaktır (Okin, 1998, s. 667). Bunun sebebi, bahsi geçen yasaların düzenlemekle sorumlu oldukları aile alanının, kültürün gelecek nesillere aktarımı, yani reprodüksiyonu için birincil öneme sahip olmasıdır. Yalnız bu alanın "emsalsiz kültürel özlerini" ve "ulusal ferdiyetlerini" korumak derdindeki muhafazakâr kültürlerin kontrolü altına girmesi, kadın-erkek eşitsizliğine yol açabilir.

Devletlerin aksine, birçok azınlık grubu, özellikle de bir toprak parçası üzerinde yoğunlaşmamış olanlar, mensuplarını resmi araçlarla belirleyecek veya vergilendirecek güce ve yetkiye sahip olmadıkları için, bu gruplara mensup kadınların kimlerle evlendiklerinin, kimlerden çocuk sahibi olduklarının ve kimlerle cinsel ilişkiye girdiklerinin kontrolü, bir azınlık grubunun mensuplarını mensubu olmayanlardan ayırmasını mümkün kılan en temel mekanizmalardan biridir (Shachar, 1998, s. 293; Shachar, 2000, s. 75). Ayrıca birçok çoğunluk kültürü gibi birçok azınlık kültürünün de ataerkil olmasından ve kadınları, kültürü gelecek nesillerde yeniden üreten domestik yetiştiriciler olarak görmesinden dolayı, birçok muhafazakâr azınlık grubu için kadınların nasıl giyindiklerinin, toplum içerisinde nasıl davrandıklarının, sosyal yaşamlarını nasıl 
sürdürdüklerinin, hangi normlar aracılı̆̆ıyla eğitildiklerinin, çocukları ve kariyerleri arasında nasıl bir ilişki kurduklarının kontrol altına alınması, "emsalsiz kültürel özlerini" ve "ulusal ferdiyetlerini" korumak isteyen muhafazakâr azınlık grupları tarafından elzem addedilmektedir (Okin, 2002, s. 221; Shachar, 1998, s. 293). Bu gibi durumlarda, azınlık-içindekiazınlıkların ulus kültürüne alternatif yorum getirmelerinin, "emsalsiz kültürel özlerini" ve "ulusal ferdiyetlerini" koruma derdindeki azınlık gruplarının muhafazakâr kültür yorumlarınca toplum ve aile baskısına maruz bırakılmaları ve hatta kültüre ihanetle suçlanmaları oldukça muhtemeldir.

Sonuç olarak, etnik ve ulusal azınlıkları cinsel azınlıklara yeğlemek, birinci gruptakileri pozitif haklarla donatırken ikinci gruptakiler için negatif haklarla yetiniyor olmak; yani çoğunluk kültüründe olması gerektiği gibi azınlık kültüründe de dominant kültürün kolektif ve çoğulcu transformasyonu için ne yapılmalı sorusunu kültürel hak söylemi içerisine sokacak teorik araçlar geliştirmemek, reform peşindeki kadınları ve diğer azınlık-içindeki-azınlık gruplarını dominant azınlık kültürüne yem etmek anlamına gelebilir. Bir sonraki bölümde, bu tür bir transformasyonu mümkün kılmak adına "diyalog" kavramını kültürel hak tartışmaları içerisine sokan Miller'ın (çok)ulusalcı liberalizmi incelenecek ve onun Kymlicka ve Tamir'e yöneltilen eleştirilerle başa çıkıp çıkamayacağına bakılacaktır.

\section{Miller ve Kültürel Diyalog}

Miller, Kymlicka ve Tamir felsefelerinde olduğu gibi, ulus kültürünün, o kültüre mensup bireyler için neyin anlamlı/neyin anlamsız olduğunu belirleyen anlam bağlamı işlevi gördügüüü; dolayısıyla "bireyin [toplumsal] kimliğini kazanmasının ve [anlamlı] seçimler yapabilmesinin önkoşulu" olarak algılanması gerektiğini savunur (Miller, 1995, s. 110). Yalnız Miller da Tamir gibi ve Kymlicka'nın aksine, ulus kültürünün bir ve tek anlam bağlamı olmadığını, ulusal aidiyetin toplumsal kimlik kazanımında dini veya toplumsal cinsiyet bağlamlarını dışlamak zorunda olmadığını vurgular (Miller, 1995, s. 11). Miller için, yine Tamir'de olduğu gibi, ulus olmanın bir önkoşulu, o ulusa mensup bireylerin ulus bilincine sahip olmaları, yani birbirlerini "yurttaş" olarak algılamaları ve yurttaşlığ belirleyen ortak özelliklere sahip olduklarına "inanmaları"dır (Miller, 1995, ss. 22-23). Ayrica Miller da ulusların tarihsel kurgular olduklarını iddia eder. Ulus denen varlık, "yazılı dilin suni bir şekilde oluşturulup" 
dilsel azınlıklara empoze edilmesi, ulusun günümüz sınırlarını oluşturan tarihsel ve sosyo-politik tesadüfler, ulusal özelliklerin çağdaş versiyonunun geçmiş zamanlara yansıtılmasıyla oluşan ama gerçeği yansitmayan tarihsel süreklilik hissi ve tüm bu sürecin unutulması veya çarpitılması sonucu ortaya çıkan bir olgudur (Miller, 1995, ss. 33-35).

Miller'a göre, kurgusal varlıklar olmalarına rağmen, uluslar özyönetim hakkına sahip olmalıdır; çünkü yukarıda gördüğümüz gibi ulus kültürü, bireylerin toplumsal kimliklerine kavuşmalarının ve anlamlı seçimler yapabilmelerinin bir önkoşuludur. Daha da önemlisi, ulus kültürünün "kamusal boyut"u vardır (Miller, 1995, s. 87). Başka bir deyişle, ulus kültürü toplumun "siyasi eylemleri"ne, "kamu binalarının mimarisi"ne, "[kamusal] eğitimin içeriği"ne, "medyanın ve filmlerin karakteri"ne yansır (Miller, 1995, s. 87). Dolayısıyla, ulus kültürünün korunması ve reprodüksiyonu, kamusal alanın ulusal kontrolüne bağlı ve bağımlıdır. Ancak çokuluslu ulus-devletlerde kamusal alan dominant çoğunluğun kültürünü yansıtır ve ulusal azınlıkların kültürlerini marjinalleştirip ulusal azınlık mensuplarının anlamlı seçimler yapmalarına ket vurur (Miller, 1995, s. 88). Bu yüzden de ulusal azınlıkların, kendi kültürlerini kamusal alana yansitabilmelerini mümkün kılan öz-yönetim hakkı ile donatılmaları gerekmektedir. Miller için kamusal alanın ulus kültürünü yansıtmasının dolaylı faydaları da vardır. Siyasi, eğitim ve kültürel kurumları ulus kültürünü yansıtan ve böylece ortak ulusal bilinç ile ulusal aidiyet hissini canlı tutan toplumlarda insanlar birbirlerine ve siyasi otoriteye daha fazla güvenirler. Bu tür bir güven duygusu da demokratik diyalog ve refah devleti harcamaları ile toplumsal işbirliği için olmazsa olmazdır (Miller, 1995, ss. 91-92, 96-97; Miller, 2013, s. 98).

Bu noktada, daha önce sorduğumuz soruyu Miller'a da yöneltmeliyiz: Ulus kültürünün din, mezhep veya toplumsal cinsiyeti dolayısıyla azınlıkiçindeki-azınlık hayatlarını anlamsızlığa itmesi nasıl engellenebilir? Miller için bu sorunun cevabı diyalog kavramında yatmaktadır. Ulus kültürü ve o kültürü oluşturan öğeler - "ulusal geçmiş"in yorumlanması, "ulusal mensubiyet" ile ne anlaşılması gerektiği, ulusun "nasıl bir insanlar topluluğu"na tekabül ettiği, "neye inandığı" ve "gelecekte nasıl davranmak istediği" - ulus içerisindeki farklı dinsel, mezhepsel veya cinsel grupların "kolektif diyaloğu" ile belirlenmelidir (Miller, 1995, ss. 39, 127). Her grup kendi ulus yorumunu ve alt kültürünü "ortak ulusal kimlik" tanımının içerisine sokmak için diğerleriyle yarışma hakkına sahip olmalı; hiçbir grubun yorumu bu yarışta öncelikli bir statüye sahip olmamalıdır: 
"geleneksel yorumu benimseyenler, [ulus kültürünün yorumlanmasında] değişim isteyenler ile eşit koşullarda diyalog sürecine girmelidirler" (Miller, 1995, ss. 40,127). Peki, bu süreç nasıl işleyecektir? Ortak kamusal alanda ve kamu kültürünün dominant yorumunda kendilerine tarihsel süreç içerisinde yer bulamayan dini, mezhepsel veya cinsel azınlık yorumları, ulus kültürünün ve kamusal alanın her katmanına nüfuz eden gelenekselci yorum ile "eşit koşullar"a nasıl sahip olacaktır? Kısacası, gelenekselci yorumun diğer yorumlarla diyaloğu nasıl hakiki kılınacak, gelenekselci yorum diğerlerinin endişelerini niye hesaba katacak, kendi normlarını azınlık gruplarına empoze etmekten nasıl kaçınacaktır?

Miller kolektif diyaloğun hakiki olması için yapılması gereken tek şeyin, düşünce ve ifade özgürlüğü gibi bireysel/negatif hakların güvence altına alınması olduğunu söyler: "kimse ulusal sembollerin ve tarihsel olayların geleneksel yorumuna karşı gelen düşünceleri ifade ettiği için dışlanmamalı ve cezalandırılmamalıdır" (Miller, 1995, s. 128, vurgu bana ait). Başka bir deyişle, Miller'a göre dini, mezhepsel veya cinsel azınlık gruplarının siyasi alana taşınmasını, kurumsal kimliklerinin tanınmasını, kamusalalandatemsilgücünesahipolmalarını, kültürelorganizasyonlarına kamusal fon ayrılmasını ve ulusal azınlıklara tanınan öz-yönetim hakkı benzeri pozitif hakların kendi bağlamlarındaki karşılığı olan veto hakkı gibi haklara sahip olmalarını savunan "güçlü çokkültürcülük" ideolojisi reddedilmelidir (Miller, 1995, ss. 120, 132). Bunun en önemli nedeni din, mezhep veya toplumsal cinsiyet bağlamlarındaki pozitif hakların, bu bağlamlardaki dominant yorumu "kemikleştirme" ve "katılaştırma" tehlikesi taşıyor olduğudur (Miller, 1995, ss. 153-154; Miller, 1999, s. 114). Örneğin kadınlık toplumsal kimliği "ataerkil" perspektiften de, "radikal lezbiyenlik" perspektifinden de, herhangi bir etnik veya dini kimliğin perspektifinden de yorumlanıp icra edilebilir (Miller, 1999, ss. 112-113). Bu durumda kadın kuruluşlarına "özel temsil hakkı" veya "veto hakkı" benzeri pozitif haklar tanımak dominant kadınlık yorumunufarklı kadınlık yorumlarını dışlamak pahasına-kadın-olmak ne demek tartışmalarından muaf kılıp kemikleştirebilir/katılaştırabilir (Miller, 1999, s. 114).

Ne var ki Miller'ın "güçlü çokkültürcülük" ideolojisini reddetmek ve ulusal azınlıklar için pozitif hakları uygun görürken diğer azınlık grupları için negatif hakları önermek amacıyla kullandığı argüman, oldukça sorunlu bir argümandır; çünkü Miller şu soruların cevabını veremez: İlk olarak, niye ulusal azınlıklara pozitif haklar tanımak ulusal azınlık 
kültürlerinin dominant yorumunu kemikleştirmiyor/katılaştırmıyor $\mathrm{da}$, benzer haklar dini, mezhepsel veya toplumsal cinsiyet gruplarina tanındığında kemikleşme/katılaşma tehlikesi doğuyor? Niye pozitif haklara sahip ulusal azınlıkların, kolektif diyalog aracılığıyla, kendi içlerindeki farklılıkları bastırmadan herkesi kapsayacak çoğulcu bir kültür üretebileceklerine inanılıyor da, ayn iyimserlik dini, mezhepsel veya toplumsal cinsiyet grupları için gösterilmiyor? İkincisi, eğer bireysel/ negatif haklar dini, mezhepsel veya cinsel azınlıkların diyalog yolu ile kendi perspektiflerini toplumsal çoğunluğa anlatmaları, toplumsal çoğunluktan kültürel endişeleri hakkında iyi niyet görmeleri ve böylece kültürel marjinalizasyondan kurtulmaları için yeterli oluyorsa, niye benzer haklar ulusal azınlıklar için yeterli olmuyor? Başka bir deyişle, niye düşünce ve ifade özgürlüğünü icra etmekten alıkonmamak ulusal çoğunluk ile ulusal azınlık kültürlerinin diyalog sürecini başlatıp, hem çoğunluğun hem de azınlığın alt-kültürlerini yansıtan ortak bir kültür üretmek için yeterli görülmüyor? Kısacası, bir azınlık grubunu (ulusal azınlıklar), diğerlerinden (örneğin cinsel azınlık gruplarından) ayıran nedir-özellikle aynı ulus kültürünün varlığının korunmasında ve reprodüksiyonunda olduğu gibi, cinsel kültürün varlığının korunmasının ve reprodüksiyonun da kamusal alanın hangi grup tarafından kontrol edildiğine bağlı olduğu düşünüldüğünde? Örneğin günümüz toplumlarında heteroseksüel çoğunluğun romantik ilişkilere ve toplumsal cinsiyete dair değerleri, tercihleri ve deneyimleri sinema endüstrisinden profesyonel davranış biçimlerine, moda endüstrisinden profesyonel giyim tarzına, sağlık politikaları belirlerken yapılan varsayımlardan aile veya iş hukukunu şekillendirirken kullanılan kıstaslara kadar birçok toplumsal ürüne nüfuz ediyor ve neyin "normal"/neyin "anormal," neyin "uygun"/ neyin "uygunsuz" olduğunu tek taraflı belirliyor.

Sonuç olarak Miller, azınlık-içindeki-azınlıkları muhafazakâr azınlık gruplarına yem etmemek için diyalog kavramını (çok)ulusalcı liberalizminin içerisine yerleştirmiş; ama bunu, diyaloğu mümkün kılacak mekanizmaları tartışmaya açmadan ve diyaloğun neden bir bağlamda güvenilir bir araç iken diğer bağlamlarda güvenilmez olduğuna açıklık getirmeden yapmıştır. Dolayısıyla, Kymlicka ve Tamir felsefelerinde olduğu gibi, Millercı (çok)ulusalcı liberalizmde de azınlık-içindekiazınlıklar sorunu ile başa çıkacak teorik araçlar geliştirilememiştir. Bir sonraki bölümde, azınlık-içindeki-azınlıklar sorununa çözüm üretemeyen (çok)ulusalcı liberalizmin, içerisinde nasıl bir anti-liberalizme kayma tehlikesi barındırdığı Raz, Margalit ve Halbertalcı (çok)ulusalcılık 
üzerinden gösterilecektir.

\section{Raz, Margalit, Halbertal ve Grup Hakkı}

Raz ve Margalit "kapsayıcı kültür" adını verdikleri, "hayatın çeşitli ve önemli yönlerini kapsayan ortak bir kültüre ve karaktere sahip gruplar" in öz-yönetim hakkı ile donatılmaları gerektiğini savunur (Margalit \& Raz, 1990, ss. 443-444). Kapsayıcı kültürlere etnik ve ulusal gruplar gibi bazı "dini" ve "rrksal" gruplar da sahip olabilir (Margalit \& Raz, 1990, s. 447). Ulusal gruplar bağlamında, "hayatın çeşitli ve önemli yönleri" yle "ulusal mutfak, nevi şahsına münhasır mimari stil, ortak dil, ulusa özgü edebi ve sanatsal gelenekler, ulusal müzik, adetler, giyim, seremoniler ve bayramlar" anlaşılır (Margalit \& Raz, ss. 443-444). Bu tür grupların özelliği kapsayıcı kültürleri sayesinde mensupları için anlam bağlamı olma işlevi görmeleridir. $\mathrm{Bu}$ da onları bireysel özgürlüklerin icrası için önkoşul olma özelliği ile donatır; çünkü "özgürlük seçeneklerin varlığına bağlı," seçenekler ise "ortak anlamlara ve pratiklere" bağımlıdır (Raz, 1995, s. 176). "Mesleki kariyer seçenekleri," “boş zaman aktiviteleri," "yabancılarla ve tanıdıklarla olan ilişkilerin doğasını belirleyen adetler ve alışkanlıklar," "eşler ve diğer aile bireyleri arasındaki beklentilerin ve tutumların yapısı" ile "kişinin empati kurabileceği yaşam tarzları" grup kültürünün karakteristik özellikleriyle şekillenir (Margalit \& Raz, 1990, s. 444). Başka bir deyişle, grup kültürü "neyin uygun ve neyin uygunsuz, neyin değerli ve neyin değersiz" olduğunu belirleyip mensupları için "yapılabilir olanın limitlerini" ve "hayal edilebilir olanın sınırlarını" çizer (Margalit \& Raz, 1990, ss. 448-449). Tüm bu sebeplerden ötürü, kapsayıcı bir kültüre mensup olmak, bireylerin toplumsal kimliklerini kazanırken "kendilerini özdeşleştirecekleri temel olgulardan biri" olarak algılanmalıdır (Margalit \& Raz, 1990, s. 445). Dolayısıyla, bireylerin "esenlikleri" ve "öz-saygıları," hayatın birçok alanında kişiye farklı seçenekler sunacak kadar zengin ve hem mensupları hem de mensubu olmayanlar tarafından saygı duyulan bir kültüre sahip olmalarına, bu kültürün korunmasına ve geleceği ile zenginliğinin o kültür ile özdeşleşen, kendi kaderini belirleme hakkı ve kurumlarına sahip gruplarca şekillendiriliyor oluşuna bağlıdır (Margalit \& Raz, 1990, ss. 448-449). Son olarak, bahsi geçen kültürlere üyelik "başarı" ile değil, "aitlik" ile elde edilir; çünkü insanlar bir ulus kültürünün üyesi olmak adına herhangi bir alanda uzmanlaşmış olmaya ihtiyaç duymazlar (Margalit \& Raz, 1990, s. 446).

Peki ulus kültürünün "uygunsuz" ve "değersiz" addettiği, böylece 
"hayal edilebilir" alanın dışına attığı dinsel pratikleri veya geleneksel olmayan kadınlık ve erkeklik yorumlarını hayatlarının merkezine koyan dini, mezhepsel veya cinsel azınlık-içindeki-azınlık gruplarının korunması için ne yapılması gerekmektedir? Heteroseksist veya ataerkil bir ulus kültürü, kadınların, geylerin, lezbiyenlerin veya transseksüellerin ihtiyaçları, yaşam tarzları ve endişeleri ile çatıştı̆̆ında ne yapılmalıdır? Raz ve Margalit bu soruları azınlık-içindeki-azınlıklarca oluşturulan çoğulculuğu tamamen önemsizleştirerek yanıtlar. Raz ve Margalit için bireyci bakış açısını terk etmemek ve bireysel endişeleri hesaba katmak adına öz-yönetim hakkının "toplumun her kesimi"nin onayına/ sözleşmesine sunulması ve kültürün yapısını belirleyen konularda dinsel, mezhepsel veya cinsel azınlıklara "veto hakkı" gibi hakların tanınması gerektiği düşüncesi oldukça "cezbedici," ama reddedilmesi gereken bir düşüncedir (Margalit \& Raz, 1990, s. 456). Bunun nedeni, öz-yönetimin tek bir birey tarafından kullanılamayacak grup pratiği olduğu, öz-yönetim hakkının bireye değil gruba verilen kolektif bir hak olduğu, kültürel aidiyetin bireysel başarı ile değil grup üyeliği ile geldiği; dolayısıyla öz-yönetim tartışması içerisine, çıkış noktasını kültürsüz bireyden alan "sözleşmeci" modelin sokulamayacak olduğu gerçeğidir (Margalit \& Raz, 1990, s. 456; Raz, 1986, s. 208). Başka bir deyişle, öz-yönetim hakk1 gruba, yani "yerel çoğunluğa" verilen bir haktır; çoğunluğa mensup olmayanların endişelerini hesaba katmak önemli olsa da, azınlık-içindekiazınlıkların hesaba katılma "hakk1" yoktur (Margalit \& Raz, 1990, s. 459).

Ne var ki bu argüman kavramsal olarak oldukça sorunlu bir argümandır; çünkü grup hakları bireyler tarafından kullanılabilir ve bazı bireysel özgürlükler ancak ve ancak gruplar tarafından icra edilebilir. Örneğin gruba ait bir hak olan anadilde savunma hakk1, sadece bireyler tarafından kullanılabilen bir haktır. Toplanma ve gösteri hakkı gibi bireysel bir hak ise, ancak ve ancak bir grup veya kolektif aracilığıyla uygulamaya sokulabilir: Bireyler tek başlarına toplanma özgürlüklerini icra edemezler. Bahsi geçen argümanın kavramsal olarak sorunlu bir argüman olması bir yana; kültürel hakları gruba verilen haklar olarak formüle etmek ve azınlık hakları tartışmasında bireysel endişeleri göz ardı etmek, azınlıkiçindeki-azınlıkları yerel çoğunluğun dominasyonu altına sokmak ve azınlık haklarının amacı olan bireylerin anlamlı seçimler yapabilmelerini mümkün kılmak idealini yok etmek demektir. Bu tehlikenin en iyi örneklerinden birini Margalit'in Halbertal ile birlikte yazdığg “Liberalizm ve Kültür Hakkı" adlı makalede görebiliriz. 
Margalit ve Halbertal makalelerine "kültür hakk1"nın bir grup hakkı olduğu iddiasıyla başlarlar ve bir kişi veya grubun herhangi bir şeye hakkının olmasını, "diğerlerini yükümlülük altına sokmak için yeter sebep" olarak tanımlarlar (Margalit \& Halbertal, 2004, s. 537). Buradan çıkan sonuç, kültürel haklara sahip bir grubun, hegemonik yorumun perspektifinden yorumladığı kültür versiyonunu korumak için, mensuplarını bazı yükümlülükler altına sokma hakkına sahip olmasıdır. Başka bir deyişle yerel çoğunluk, mensuplarından, mensupluklarını reddetmedikleri müddetçe, ulus veya din kültürünün muhafazakâr yorumuna uygun davranmaların ve bu yoruma uymayan eylemlerden kaçınmalarını bekleme hakkına sahiptir-bu yorum her ne kadar antiliberal olsa da. Margalit ve Halbertal'ın anti-liberal yoruma verdikleri örnek yeterince eğiticidir: İsrail'deki Ultra-Ortodoks kültür.

$\mathrm{Bu}$ kültürün, mensuplarının hayatlarında karışmadığı herhangi bir alan yoktur... [Ö]rneğin evde televizyon sahibi olmak UltraOrtodoks toplumda yasaktır. Benzer bir şekilde, cemaatin yayınladığı gazetelerden başka bir gazete okumak da yasaktır... Bazı Ultra-Ortodoks cemaatlerde, cemaatin aşırı püritenliğine uygun davranmayanları takip eden, rapor eden, tehdit eden, hatta onlara karşı şiddet eylemlerinde bulunan "ahlak mangaları" bulunmaktadır... [Ayrıca] mensuplarının cemaate ekonomik bağlılıkları da mutlaktır; öyle ki her türlü [ahlaki] sapma boykot ile cezalandırılır (Margalit \& Halbertal, 2004, ss. 530-531).

Ultra-Ortodoks toplumda en önemli değer Tevrat eğitimidir... Okul müfredatı tamamen cemaatin elindedir ve kız çocukları ile erkek çocuklarının eğitiminde ayrımcılık yapılmakta, kızlar ve erkekler farklı konularda eğitim görmektedir... Temel aritmetik dışında erkek çocukları neredeyse hiçbir seküler konuda eğitilmemektedir (Margalit \& Halbertal, 2004, ss. 531-532).

Ultra-Ortodoks cinsel ahlak kadınların "mütevazı" giyinmelerini gerektirir. Bu gereklilik, Ultra-Ortodoks mahallelere yolu düşen her kadın için geçerlidir (Margalit \& Halbertal, 2004, s. 544).

Margalit ve Halbertal İsrail'deki Ultra-Ortodoks cemaatler benzeri azınlık gruplarının, kültürlerini korumak adına yukarıda bahsi geçen anti-liberal, ayrımc1, baskıcı ve yaşam seçeneklerini sınırlayıcı uygulamalardan alıkonmama hakkına sahip olmaları bir yana; "eğitim kurumları ile evlilik 
ve aileyi ilgilendiren konularda da otonomi sahibi olabilmeleri için" devlet tarafından "desteklenmeleri" gerektiğini savunur (Margalit \& Halbertal, 2004, s. 545). Yalnız Ultra-Ortodoks cemaatler evlilik ile aileyi ilgilendiren konularda da anti-liberal ve ayrımcıdırlar. Örneğin Halakhik yasalara göre bir kadının cemaatin onaylayacağ (izin) alması gerekmektedir-erkekler için böyle bir zorunluluk yoktur. Get almadan ve cemaatin onaylamadığı yasalara göre eşinden boşanıp başka bir erkekle cinsel ilişkiye giren kadınlar ve onların soyundan gelenler cemaat üyeliklerini kaybederler-bu, erkekler için geçerli değildir. Bu da kadınların eşlerinden get alabilmek adına evlilik süresince elde edilen varlıkların bölüşümünden çocuk velayetine kadar birçok konuda şantaja ve ekonomik sömürüye açık olmaları anlamına gelir (Reitman, 2005, s. 192; Shachar, 2000, s. 77). Ne var ki bireyler anlamlı seçimler yapabilsinler diye savunulan kültürel hakları, azınlık-içindeki-azınlıkların yaşam seçeneklerini kısıtlayacak veya onları ya bireysel seçimlerini anlamlı kılan kültürel mensubiyetini reddedersin ya da bireysel özgürlüklerini icra etmekten, hayatını kendi koyduğun kurallar çerçevesinde yaşamaktan ve bunu yapmanı mümkün kılacak eğitimden vaz geçersin tehdidine maruz bırakacak şekilde formüle etmek, kendi içerisinde çelişkili bir davranıştır.

\section{Sonuç}

Sonuç olarak, liberal çokkültürcülügüun en önemli versiyonlarından biri olan (çok)ulusalcı liberalizm yeterince çoğulcu değildir. Bunun sebebi, (çok)ulusalcı yazarların ya ulus kültürünü dinsel, mezhepsel veya cinsel kültüre yeğlemeleri ve dolayısıyla dinsel, mezhepsel ve cinsel azınlıkların endişelerini hesaba katmadan çokkültürcülük teorileri geliştirmeleri; ya da ulus kültürünü dinsel, mezhepsel veya cinsel kültür karşısında öncelikli bir konuma yerleştirmemelerine rağmen, ulus kültürünün diğer kültürleri de içerisine alacak denli çoğulcu olmasını mümkün kılacak teorik araçlar geliştirememeleridir. Yalnız bu, ne genelde çokkültürcülügüü, ne de özelde (çok)ulusalcı liberalizmin reddedilip, kültürel çoğulculuk sorununa kültürel tarafsızlık veya iyi niyetli ihmal kavramlarıyla yaklaşan bireyci liberalizme geri dönülmesi gerektiği anlamına gelir. (Çok)ulusalcı teorilerin gösterdiği gibi, kültürel tarafsızlık ve iyi niyetli ihmal anlayışları genellikle azınlıkların dezavantajına olan mitlerdir. Liberal felsefenin yapması gereken, ne kültürü adalet tartışmalarının dışında tutmak, ne de kültürün korunması adına bireysel hakları ve kültür-içi çoğulculuğu unutmaktır. Aksine, yapılması gereken şu sorulara ve endişelere kendi içerisinde tutarlı cevaplar sunabilen 
çokkültürcülük teorileri geliştirmektir: Bireysel hak ve özgürlüklerin garanti altına alındığı toplumlarda kültürel azınlık haklarına ne kadar, hangi bağlamlarda ve hangi amaçla ihtiyaç vardır? Kültürel haklar bireysel hakların garanti altına alınmalarını doğrudan veya dolaylı olarak tehdit eder mi? Bireysel haklar ile kültürel haklar çatıştığında hangisinin, niye önceliği olmalı veya çatışma nasıl engellenmelidir? Ortak kültürün homojen olamayacağı gibi, azınlık kültürleri de heterojen değil midir? Azınlık hakları, azınlık kültürlerinin hegemonik versiyonunu koruyarak azınlık-içindeki-azınlıkları ikinci sınıf vatandaş konumuna düşürür mü? Kültürel haklar etnik şovenizmi, diyalogsuzluğu ve kültürlerin statik varlıklarmışçasına fosilleştirilmeleri tehlikesini doğurur mu? En önemlisi, hem toplumsal çoğunluk, hem ulusal azınlık, hem de azınlık-içindekiazınlık kültürlerini etnik şovenizme veya fosilleşmeye yol açmadan korumak ve birbirleriyle diyalog halinde olmalarını sağlamak için bireysel ve kültürel haklar nasıl bir araya gelmeli, hangi hak ve kaynak dağılımı mekanizmaları kullanılmalı, azınlık temsilcileri nasıl ve kimler arasından seçilmelidir?

Aret Karademir, Orta Doğu Teknik Üniversitesi, Türkiye

\section{Kaynakça}

Benhabib, S. (2002). The Claims of Culture: Equality and Diversity in the Global Era. Princeton: Princeton University Press.

Carens, J. (2010). Culture, Citizenship, and Community: A Contextual Exploration of Justice as Evenhandedness. New York: Oxford University Press.

Gurr, T. (2000). Peoples versus States: Minorities at Risk in the New Century. Washington: United States Institute of Peace.

Kymlicka, W. (1995). Multicultural Citizenship: A Liberal Theory of Minority Rights. New York: Oxford University Press.

Kymlicka, W. (2001). Politics in the Vernacular: Nationalism, Multiculturalism, and Citizenship. New York: Oxford University Press.

Kymlicka, W. (2007). Multicultural Odysseys: Navigating the New International Politics of Diversity. New York: Oxford University Press.

Levy, J. (2000). The Multiculturalism of Fear. New York: Oxford University Press. Levy, J. (2003). Indigenous Self-Government. Secession and Self-Determination içinde. Der. S. Macedo \& A. Buchanan. New York: New York University Press.

Margalit, A. \& Halbertal, M. (2004). Liberalism and the Right to Culture. Social Research: An International Quarterly 71, ss. 529-548.

Margalit, A. \& Raz, J. (1990). National Self-Determination. The Journal of Philosophy 87, ss. 439-461. 
McGarry, J. (1998). Demographic Engineering: The State-Directed Movements of Ethnic Groups as a Technique of Conflict Resolution. Ethnic and Racial Studies 21, ss. 613-638.

Mill, J. S. (1972). Considerations on Representative Government. Utilitarianism, Liberty, Representative Government içinde. Der. H. Acton. London: J. M. Dent.

Miller, D. (1995). On Nationality. New York: Oxford University Press.

Miller, D. (1999). Group Identities, National Identities and Democratic Politics. Toleration, Identity and Difference içinde. Der. J. Horton \& S. Mendus. New York: Palgrave Macmillan.

Miller, D. (2013). Justice for Earthlings: Essays in Political Philosophy. Cambridge: Cambridge University Press.

Modood, T. (2013). Multiculturalism: A Civic Idea (2nd ed.). Cambridge: Polity Press.

Okin, S. M. (1998). Feminism and Multiculturalism: Some Tensions. Ethics 108, ss. 661-684.

Okin, S. M. (2002). 'Mistresses of Their Own Destiny': Group Rights, Gender, and Realistic Rights of Exit. Ethics 112, ss. 205-230.

Penz, P. (1992). Development Refugees and Distributive Justice: Indigenous Peoples, Land and the Developmentalist State. Public Affairs Quarterly 6, ss. 105-131.

Rawls, J. (1999). A Theory of Justice (revised edition). New York: Oxford University Press.

Rawls, J. (2005). Political Liberalism (expanded edition). New York: Columbia Press.

Raz, J. (1986). The Morality of Freedom. New York: Oxford University Press.

Raz, J. (1995). Multiculturalism: A Liberal Perspective. Ethics in the Public Domain: Essays in the Morality of Law and Politics (revised edition) içinde. New York: Oxford University Press.

Reitman, O. (2005). On Exit. Minorities-within-Minorities: Equality, Rights and Diversity içinde. Der. A. Eisenberg \& J. Spinner-Halev. Cambridge: Cambridge University Press.

Shachar, A. (1998). Group Identity and Women's Rights in Family Law: The Perils of Multicultural Accommodation. The Journal of Political Philosophy 6, ss. 285305.

Shachar, A. (2000). On Citizenship and Multicultural Vulnerability. Political Theory 28, ss. 64-89.

Tamir, Y. (1991). The Right to National Self-Determination. Social Research 58, ss. 565-590.

Tamir, Y. (1993). Liberal Nationalism. Princeton: Princeton University Press.

Tamir, Y. (1995). The Enigma of Nationalism. World Politics 47, ss. 418-440.

Tamir, Y. (1999). Against Collective Rights. Multicultural Questions içinde. Der. C. Joppke \& S. Lukes. New York: Oxford University Press.

Weinstock, D. (2002). Citizenship and Pluralism. The Blackwell Guide to Social and Political Philosophy içinde. Der. R. Simod. Malden: Blackwell Publishers. 